Arq. Bras. Med. Vet. Zootec., v.70, n.1, p.147-152, 2018

\title{
Seroepidemiology of Neospora caninum among goats (Capra hircus) in the state of Paraíba, northeastern Brazil
}

[Soroepidemiologia de Neospora caninum em caprinos (Capra hircus) do estado da Paraíba, Nordeste do Brasil]

B.M.A. Braz', J.D.M. Valente ${ }^{2}$, E.M.C. Villalobos ${ }^{3}$, M.C.C.S.H. Lara ${ }^{3}$, C.A.L. Machado ${ }^{2}$, I.C. Barbosa ${ }^{1}$, V.S.P. Melo ${ }^{1}$, D.T. Stipp ${ }^{1}$, I.R. Barros-Filho ${ }^{2}$, A.W. Biondo ${ }^{2}$, T.S.W.J. Vieira ${ }^{2}$, R.F.C. Vieira ${ }^{2 *}$

\author{
${ }^{1}$ Universidade Federal da Paraíba - Areia, PB \\ ${ }^{2}$ Universidade Federal do Paraná - Curitiba, PR \\ ${ }^{3}$ Laboratório de Raiva e Encefalites Virais - Instituto Biológico, São Paulo, SP
}

\begin{abstract}
Although goat dairy farms in Brazil may have a higher risk of infection by Neospora caninum than beef farms, risk factor evaluation on a representative population remains to be fully established in Brazil. Accordingly, this study aimed to establish the occurrence of anti- $N$. caninum antibodies and factors associated with exposure in 406 blood samples from five dairy and three beef goat farms in the state of Paraíba, northeastern Brazil. Anti-N. caninum antibodies were detected by indirect immunofluorescence assay (IFA), with samples considered positive when reacting with dilution $\geq 1: 50$. A total of 106/406 goats $(26.11 \%$; $95 \%$ CI: $21.96-30.72 \%)$ were seroreactive comprising $2 / 61$ (3.28\%), $10 / 45(22.22 \%)$, $13 / 50(26.00 \%), 17 / 51(33.33 \%)$ to $29 / 46(63.04 \%)$ in dairy farms, and from $3 / 54(5.56 \%), 12 / 50$ (24.00\%) to 20/49 (40.82\%) on the beef farms. No significant associations were found in relation to age, gender, dairy versus beef farms, occurrence of abortions or mummified fetuses, and seroreactivity to $N$. caninum ( $\mathrm{P}>0.05)$. In conclusion, goat farms in the state of Paraíba showed the highest occurrence of anti- $N$. caninum antibodies to date in Brazil.
\end{abstract}

Keywords: IFA, neosporosis, seroprevalence, small ruminants

\section{RESUMO}

Embora as criações caprinas de leite no Brasil possam ter maior probabilidade de risco de infecção por Neospora caninum do que as de carne, a avaliação dos fatores de risco em uma população representativa ainda não está totalmente estabelecida no Brasil. Dessa forma, este estudo teve por objetivo estabelecer a soroprevalência de N. caninum e seus fatores associados à exposição em 406 amostras de sangue de cinco fazendas de leite e três de corte provenientes do estado da Paraíba, região Nordeste do Brasil. A detecção de anticorpos anti-N. caninum foi realizada utilizando-se a reação de imunofluorescência indireta (RIFI), com as amostras consideradas positivas na diluição $\geq 1: 50$. No total, 106/406 (26,11\%; IC 95\%: 21,96-30,72\%) caprinos foram sororreagentes, variando de $2 / 61$ (3,28\%), $10 / 45$ (22,22\%), $13 / 50$ (26,00\%), $17 / 51(33,33 \%)$ a 29/46 (63,04\%) em fazendas de leite, e de 3/54 (5,56\%), 12/50 $(24,00 \%)$ a 20/49 (40,82\%) em fazendas de corte. Não foram observadas associações significativas entre idade, sexo, criação de leite e carne, ocorrência de abortamentos ou fetos mumificados $e$ sororreatividade para $\mathrm{N}$. caninum $(P>0,05)$. Em conclusão, fazendas de caprinos da Paraíba mostraram as mais altas ocorrências de anticorpos anti-N. caninum até o momento no Brasil.

Palavras-chave: neosporose, pequenos ruminantes, RIFI, soroprevalência

Recebido em 30 de novembro de 2016

Aceito em 15 de dezembro de 2016

*Autor para correspondência (corresponding author)

E-mail: rvieira@ufpr.br 


\section{INTRODUCTION}

Neospora caninum is an obligate intracellular parasite and infection has been reportedly implicated in worldwide livestock losses, causing reproductive problems such as abortion and infertility in several species, including goats (Dubey et al., 1996; Moore, 2005). Since Brazilian goat farms have been mostly $(90.10 \%)$ located on Northeastern Brazil (Instituto..., 2013), which has historically reported sanitary problems due to inappropriate management practices (Pinheiro et al., 2000), identification of causative agents of reproductive losses may be crucial for dairy and beef goat production.

A series of reports on the presence of infected goats with $N$. caninum has been published worldwide. Prevalence studies performed in Europe and Asia have showed data ranging from 2.3-15.5\% (Cobadiova et al., 2013; Czopowicz et al., 2011; Diakoua et al., 2013; GarciaBocanegra et al., 2012; Iovu et al., 2012; Moreno et al., 2012) and from 2.0-8.6\% (Abo-Shehada e Abu-Halaweh, 2010; Nasir et al., 2012; Liu et al, 2015), respectively. In Brazil, several States have reported anti- $N$. caninum antibodies in goats, with seroprevalence data ranging from 1.0526.60\% (Lima et al., 2008; Silva et al., 2009; Faria et al. 2007; Topazio et al., 2014; Anderlini et al., 2011; Figliuolo et al., 2004; Varaschin et al., 2011; Andrade et al., 2013; Uzêda et al., 2007; Modolo et al., 2008; Costa et al., 2012; Moraes et al., 2011; Tembue et al., 2011) (Figure 1).

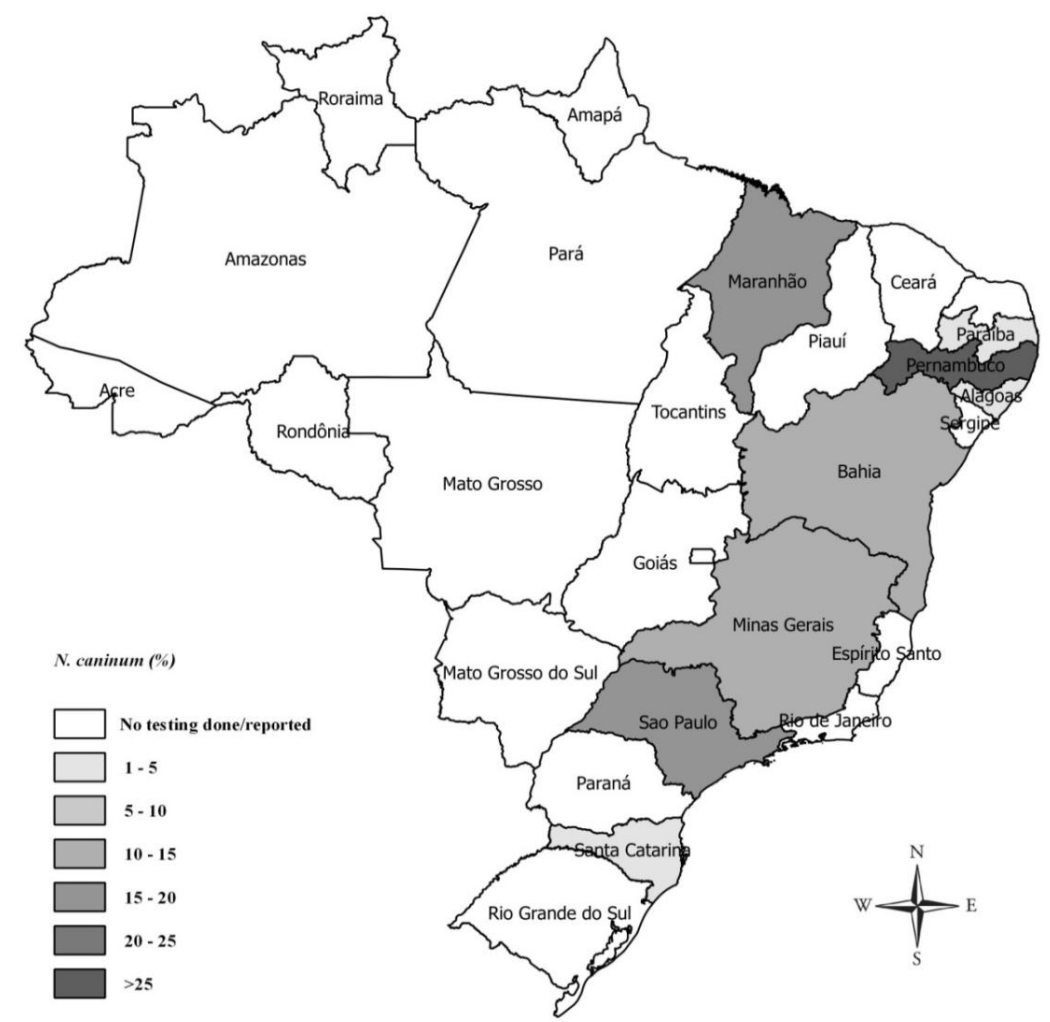

Figure 1. Geographical illustration of serologic occurrence of Neospora caninum in goats from Brazil based referenced data. Geographic Information System, Quantum GIS, Version 2.8 WIEN.

Interestingly, dairy farms in Brazil may have a higher risk likelihood of infection than beef farms, probably due to the longer lifetime of dairy herds on the farm. Despite the seroprevalence data, risk factor evaluation on a representative population remains to be fully established in Brazil. Accordingly, this study aimed to evaluate the occurrence and factors associated with anti- $N$. caninum antibodies in dairy and beef goats in the state of Paraíba, northeastern Brazil. 


\section{MATERIALS AND METHODS}

This study was approved by the Ethics Committee for Animal Experimentation and Animal Welfare at the Federal University of Paraíba, northeastern Brazil (protocol 3305/14).

The sample size was calculated as previously described (Thrusfield, 1995). The total number of goats in the state of Paraíba was estimated at 478.000 (Instituto..., 2013) and the expected prevalence was assumed to be $50 \%$. The minimum sample size required for detecting a difference with $95 \%$ confidence level at $5 \%$ was estimated as $n=384$. A total of 406 goat blood samples (35 males and 371 females) were randomly collected from five dairy and three beef farms ( $\sim 50$ animals per farm) in the state of Paraíba.

The dairy farms were located in the following municipalities Algodão de Jandaíra ( $6^{\circ} 53.531^{\prime} \mathrm{S}$ $\left.35^{\circ} 59.096^{\prime} \mathrm{W}\right)$, Caturité I ( $7^{\circ} 24.562^{\prime} \mathrm{S} 36^{\circ}$ $0.096^{\prime}$ W), Caturité II $\left(07^{\circ} 23.261^{\circ} \mathrm{S} \quad 036^{\circ}\right.$ $\left.03.878^{\prime} \mathrm{W}\right)$, Gurjão $\left(7^{\circ} 14.747^{\prime}\right.$ S $36^{\circ} 33.084^{\circ}$ W), and Serra Branca ( $7^{\circ} 29.259^{\prime} \mathrm{S} 36^{\circ} 42.335^{\prime}$ W), while the beef farms were located at Cuité $\left(6^{\circ} 38.356^{\prime} \mathrm{S} 36^{\circ} 09.733^{\prime} \mathrm{W}\right)$, Juarez Távora $\left(7^{\circ}\right.$ $\left.09.437^{\prime} \mathrm{S} 35^{\circ} 36.051 \mathrm{~W}\right)$, and Olivedos $\left(06^{\circ}\right.$ $\left.53.039^{\prime} \mathrm{S} 36^{\circ} 13.923^{\prime} \mathrm{W}\right)$. The farms are located in two different climate regions of the state semiumid coastal and semi-arid tropical.

Blood samples were collected using commercial tubes containing separating gel clots (BD Vacutainer $^{\circledR}$, Franklin Lakes, NJ USA). These were kept at room temperature $\left(25^{\circ} \mathrm{C}\right)$ until clot retraction became visible. The samples were centrifuged at $1500 \mathrm{~g}$ for $5 \mathrm{~min}$ and the serum was then separated out, appropriately aliquoted, identified and stored at $-20^{\circ} \mathrm{C}$.

The farm owners answered an epidemiological questionnaire, which included questions on goat gender and age, abortions or mummified fetuses, and presence of dogs. Goats were age-stratified into groups of $\leq 1$ year and $>1$ year. The beef farm at Juarez Távora presented high-quality management practices and was considered to be a reference farm for statistical comparison.

The indirect immunofluorescence antibody assay (IFA) was applied to detect antibodies anti- $N$. caninum using a commercial kit (Imunoteste Neospora (RIFI) - caprino, Imunodot $^{\circledR}$, Jaboticabal, São Paulo, Brasil), in accordance with the manufacturer's instructions, except for using conjugated rabbit anti-Goat IgG-FITC as the secondary antibody. Samples were considered positive when the tachyzoites showed total peripheral fluorescence at 1:50 dilution (Lindsay et al., 1995).

The Chi-square or Fisher's exact test was used to determine whether the factors evaluated were associated with seropositivity for $N$. caninum. Odds ratio (OR), 95\% confidence interval and $\mathrm{P}$ values were calculated separately for each variable. Results were considered significantly different when $\mathrm{P}<0.05$. Data were generated and analyzed using software available free-of-charge (Epi Info ${ }^{\mathrm{TM}}$ 7.5.1.0, CDC, Atlanta, USA).

\section{RESULTS}

A total of 106/406 (26.11\%; 95\% CI: $21.96-$ $30.72 \%$ ) goats were seroreactive for $N$. caninum. All farms had at least one $N$. caninum seroreactive animal. With the exception of the dairy farm at Serra Branca, goats from all the remaining farms were more likely to be seroreactive for $N$. caninum than those from beef farm at Juarez Távora. No associations between seroreactivity to $N$. caninum and gender $(\mathrm{P}=0.1199)$, age $(\mathrm{P}=0.5881)$, occurrences of abortions $(\mathrm{P}=0.2090)$ or mummified fetuses $(\mathrm{P}=0.9851)$, and production system $(\mathrm{P}=0.32725)$ were observed. All the farms reported that dogs were present. The occurrence of anti- $N$. caninum antibodies within each variable evaluated are summarized in Table 1. 
Table 1. Occurrence of anti-Neospora caninum antibodies in eight different goat farms from Paraíba State, Northeastern Brasil and correspondent testing of risk factors

\begin{tabular}{|c|c|c|c|c|c|c|}
\hline \multirow[b]{2}{*}{ Farm } & \multirow[b]{2}{*}{ Purpose } & \multicolumn{5}{|c|}{ N. caninum (IFA) } \\
\hline & & $+/ \mathrm{n}$ & $(\%)$ & OR & $95 \% \mathrm{CI}$ & P-value \\
\hline Algodão & Dairy & $29 / 46$ & 63.04 & 29.0000 & $7.83-107.40$ & 0.00000 \\
\hline Caturité I & Dairy & $17 / 51$ & 33.33 & 8.5000 & $2.31-31.24$ & 0.00030 \\
\hline Caturité II & Dairy & $13 / 50$ & 26.00 & 5.9730 & $1.59-22.47$ & 0.00390 \\
\hline Gurjão & Dairy & $10 / 45$ & 22.22 & 4.8571 & $1.25-18.92$ & 0.01450 \\
\hline Serra Branca & Dairy & $2 / 61$ & 3.28 & 1.7353 & $0.28-10.79$ & 0.55010 \\
\hline Cuité & Beef & $20 / 49$ & 40.82 & 11.7241 & $3.21-42.86$ & 0.00002 \\
\hline Olivedos & Beef & $12 / 50$ & 24.00 & 5.3684 & $1.41-20.36$ & 0.00740 \\
\hline Juarez* & Beef* & $3 / 54$ & 5.56 & & & \\
\hline \multirow[t]{2}{*}{ Age } & $>1$ & $87 / 340$ & 25.59 & 1.17 & $0.65-2.11$ & 0.58810 \\
\hline & $\leq 1$ & $19 / 66$ & 28.79 & & & \\
\hline \multirow[t]{2}{*}{ Gender } & Male & $13 / 35$ & 37.14 & 1.7664 & $0.85-3.65$ & 0.11999 \\
\hline & Female & $93 / 371$ & 25.07 & & & \\
\hline \multirow[t]{2}{*}{ Abortion } & Yes & $89 / 355$ & 25.07 & 0.6692 & $0.35-1.25$ & 0.20900 \\
\hline & No & $17 / 51$ & 33.33 & & & \\
\hline \multirow{2}{*}{$\begin{array}{l}\text { Mummified } \\
\text { fetuses }\end{array}$} & Yes & $13 / 50$ & 26.00 & 0.9936 & $0.51-1.95$ & 0.98510 \\
\hline & No & $93 / 356$ & 26.12 & & & \\
\hline \multirow{2}{*}{$\begin{array}{l}\text { Production } \\
\text { system }\end{array}$} & Dairy & $70 / 252$ & 27.78 & 1.2607 & $0.79-2.00$ & 0.32725 \\
\hline & Beef & $36 / 154$ & 23.38 & & & \\
\hline
\end{tabular}

+, Number of positive animals; $n$, number of samples; 95\% CI, 95\% confidence interval. * Reference goat farm.

\section{DISCUSSION}

In the present study, an overall occurrence of anti- $N$. caninum antibodies of $26.11 \%$ (ranging from $3.28 \%$ to $63.04 \%$ ) was found among goats in the state of Paraíba, which is within the range found in previous Brazilian studies on goats, from $1.05 \%$ to $26.6 \%$ (Faria et al. 2007; Uzêda et al., 2007; Lima et al., 2008; Anderlini et al., 2011; Tembue et al., 2011; Moraes et al., 2011). The differences between studies may be due mainly to the type of population and sample size, management system, climatic variances, diagnostic method and the respective cut-offs used. However, in the present study, we found the highest occurrence regarding all the studies developed in Brazil. An occurrence of $63.04 \%$ was found in the dairy farm from Algodão, where the herd has less than 50 animals, there was no rotational grazing and more than one animal species was bred in the same property (data not shown). Previous studies have reported that goat breeding without any rotational grazing associated to the direct contact with other animal species, such as in the present study, may facilitate the infection by oocysts (Atwill et al., 1999).
Although previous studies reported that age (Tembue et al., 2011) and gender (Uzêda et al., 2007) were associated with seropositivity for $N$. caninum, neither age nor gender were associated with seroreactivity in the present study. The disproportionate number of female ( 371 females and 35 males) and animals $>1$ year $(340>1$ year and $66 \leq 1$ year) may have interfered in the statistical analyses. However, previous studies have stated that the lack of association between gender or age and seropositivity to $N$. caninum in goats indicates that the presence of this protozoan is homogenous among the herd (Figliuolo et al., 2004; Modolo et al., 2008).

In the present study, even though approximately $25 \%$ of the seroreactive goats were from properties with a historical of abortions or mummified fetuses, no association between these factors and seroreactivity to $N$. caninum was observed $(\mathrm{P}>0.05)$. In fact, the most common clinical manifestations of neosporosis in goats include abortions or mummified fetuses. Previous studies have stated that goats experimentally infected with $N$. caninum do not develop clinical disease (Dubey and Lindsay, 1996). Thus, other infectious (and noninfectious) agents, which unfortunately were not 
evaluated in the present study, particularly Toxoplasma gondii, may lead to similar reproductive problems and should be further investigated.

In the present study, no statistical differences were observed between dairy and beef farms $(\mathrm{P}=0.32725)$. However, the intra-group variation among dairy farms $(3.28 \%, 22.22 \%, 26.00 \%$, $33.33 \%$ and $63.04 \%)$ and beef farms $(5.56 \%$, $24.00 \%$ and $40.82 \%$ ), associated to the fact that dogs were present in all farms may have impaired statistical comparisons. Therefore, other factors associated with $N$. caninum infection, such as the type of the water source and its quality (Figlioulo et al., 2004), not covered in the present study may have accounted for this discrepancy in seropositivity. To the author's knowledge, no study to date has focused on comparisons between dairy and beef farms, and therefore this topic needs to be further addressed.

\section{CONCLUSION}

In conclusion, anti- $N$. caninum antibodies were highly prevalent in dairy and beef goats from the state of Paraíba. Even though no statistical differences between the production system and seroreactivity to this protozoon have been observed, other factors associated with infection should be further investigated. Finally, goat farms in the state of Paraíba showed the highest occurrence of anti- $N$. caninum antibodies to date in Brazil.

\section{ACKNOWLEDGEMENTS}

This study was part of a Master's degree for Beatriz Braz at the Universidade Federal da Paraíba. Beatriz Braz and Carolina Machado were sponsored by a fellowship from the Coordenação de Aperfeiçoamento de Pessoal de Nivel Superior (CAPES) at the time of the study. We thank Laysa Cordeiro and Luana Ribeiro for their assistance during blood sampling.

\section{REFERENCES}

ABO-SHEHADA, M.N.; ABU-HALAWEH, M.M. Flock-level seroprevalence of, and risk factors for, Neospora caninum among sheep and goats in northern Jordan. Prev. Vet. Med., v.93, p.25-32, 2010.
ANDERLINI, G.A.; FARIA, E.B.F.; SILVA, A.M. et al. Prevalência de anticorpos anti-Neospora caninum em caprinos no estado de Alagoas, Brasil. Vet. Zootec., v.18, p.583-590, 2011.

ANDRADE, G.D.A.S.; BRUHN, F.R.; ROCHA, C.M. et al. Seroprevalence for Neospora caninum in goats of Minas Gerais state, Brazil. Res. Vet. Sci., v.94, p.584-586, 2013.

ATWILL, E.R.; JOHNSON, EM.; PEREIRA, M.G. Association of herd composition, stocking rate, and duration of calving season with fecal shedding of Cryptosporidium parvum oocysts in beef herds. J. Am. Vet. Med. Assoc. v.215, p.1833-1838, 1999.

COBADIOVA, A.; REITEROVA, K.; DERDAKOVA, M. et al. Toxoplasma gondii, Neospora caninum and tick-transmitted bacterium Anaplasma phagocytophilum infections in one selected goat farm in Slovakia. Acta Parasitol., v.58, p.541-546, 2013.

COSTA, H.F.; STACHISSINI, A.V.M.; LANGONI, H. et al. Reproductive failures associated with antibodies against caprine arthritis-encephalitis virus, Toxoplasma gondii and Neospora caninum in goats in the state of Sao Paulo, Brazil. Braz. J. Vet. Res. Anim. Sci., v.49, p.67-72, 2012.

CZOPOWICZ, M.; KABA, J.; SZALUŚJORDANOW, O. et al. Seroprevalence of Toxoplasma gondii and Neospora caninum infections in goats in Poland. Vet. Parasitol., v.178, p.339-341, 2011.

DIAKOUA, A.; PAPADOPOULOS, E.; PANOUSIS, N. et al. Toxoplasma gondii and Neospora canivalence in num seropredairy sheep and goats mixed stock farming. Vet. Parasitol., v.198, p.387-390, 2013.

DUBEY, J.P.; LINDSAY, D.S. A review of Neospora caninum and neosporosis. Vet. Parasitol., v.67, p.1-59, 1996.

DUBEY, J.P.; MORALES, J.A.; VILLALOBOS, P. et al. Neosporosis-associated abortion in a dairy goat. J. Am. Vet. Med. Assoc., v.208, p.263-265, 1996.

FARIA, E.B.; GENNARI, S.M.; PENA, H.F. et al. Prevalence of anti-Toxoplasma gondii and antiNeospora caninum antibodies in goats slaughtered in the public slaughterhouse of Patos city, Paraíba State,Northeast region of Brazil. Vet. Parasitol., v.149, p.126-129, 2007. 
FIGLIUOLO, L.P.C.; RODRIGUESA, A.A.R.; VIANAB, R.B. et al. Prevalence of antiToxoplasma gondii and anti-Neospora caninum antibodies in goat from São Paulo State, Brazil. Small Ruminant Res., v.55, p.29-32, 2004.

GARCÍA-BOCANEGRA， I.; CABEZÓN， O.; PABÓN, M. et al. Prevalence of Toxoplasma gondii and Neospora caninum antibodies in Spanish ibex (Capra pyrenaica hispanica). Vet. J., v.191, p.257-260, 2012.

INSTITUTO BRASILEIRO DE GEOGRAFIA E ESTATÍSTICA. [Rio de Janeiro]: IBGE, 2013. Available in: <http://www.ibge.gov.br/home/estatistica/econo $\mathrm{mia} / \mathrm{ppm} / 2013 /$ default_pdf.shtm $>$. Accessed in 07 Nov. 2015.

IOVU, A.; GYÖRKE, A.; MIRCEAN, V. et al. Seroprevalence of Toxoplasma gondii and Neospora caninum in dairy goats from Romania. Vet. Parasitol., v.186, p.470-474, 2012.

LIMA， J.T.R.; AHID， S.M.M.; BARRETO JUNIOR, R.A. et al. Prevalência de anticorpos anti-Toxoplasma gondii e anti-Neospora caninum em rebanhos caprinos do município de Mossoró, Rio Grande do Norte. Braz. Vet. Res. Anim. Sci., v.45, p.81-86, 2008.

LINDSAY, D.S.; RIPPEY, N.S.; POWE, T.A. et al. Abortions, fetal death, and stillbirths in pregnant pygmy goats inoculated with tachyzoites of Neospora caninum. Am. J. Vet. Res., v.56, p.1176-1180, 1995.

LIU, Z.K.; LI, J.Y.; PAN, H. Seroprevalence and risk factors of Toxoplasma gondii and Neospora caninum infections in small ruminants in China. Prev. Vet. Med., v.118, p.488-92, 2015.

MODOLO, J.R.; STACHISSINI, A.V.M.; GENNARI, S.M. et al. Frequiência de anticorpos anti- Neospora caninum em soros de caprinos do estado de São Paulo e sua relação com o manejo dos animais. Pesqui. Vet. Bras., v.28, p.597-600, 2008.

MOORE, D.P. Neosporosis in South America. Vet. Parasitol., v.127, p.87-97, 2005.
MORAES, L.M.; RAIMUNDO, J.M.; GUIMARÃES, A. et al. Occurrence of antiNeospora caninum and anti-Toxoplasma gondii IgG antibodies in goats and sheep in western Maranhão, Brazil. Rev. Bras. Parasitol. Vet., v.20, p.312-7, 2011.

MORENO, B.; COLLANTES-FERNÁNDEZ, E.; VILLA, A. et al. Occurrence of Neospora caninum and Toxoplasma gondii infections in ovine and caprine abortions. Vet. Parasitol., v.187, p.312-8, 2012.

NASIR, A.; ASHRAF, M.; KHAN, M.S. et al. Prevalence of Neospora caninum antibodies in sheep and goats in Pakistan. J. Parasitol., v.98, p.213-215, 2012.

PINHEIRO, R.R.; GOUVEIA, A.M.G.; ALVES, F.S.F.; HADDAD, J.P.A. Aspectos epidemiológicos da caprinocultura cearense. Arq. Bras. Med. Vet. Zootec., v.52, p.534-543, 2000.

SILVA, M.S.; UZÊDA, R.S.; COSTA, K.S. et al. Detection of Hammondia heydorni and related coccidia (Neospora caninum and Toxoplasma gondii) in goats slaughtered in Bahia, Brazil. Vet. Parasitol., v.162, p.156-159, 2009.

TEMBUE, A.A.; RAMOS, R.A.; DE SOUSA, T.R. et al. Serological survey of Neospora caninum in small ruminants from Pernambuco State, Brazil. Rev. Bras. Parasitol. Vet., v.20, p.246-248, 2011.

THRUSFIELD, M. Veterinary epidemiology. London: Blackwell Science Ltd., 1995. [624p.].

TOPAZIO, J.P.; WEBER, A.; CAMILLO, G. et al. Seroprevalence and risk factors for Neospora caninum in goats in Santa Catarina state, Brazil. Rev. Bras. Parasitol. Vet., v.23, p.360-366, 2014.

UZÊDA, R.S.; PINHEIRO, A.M.; FERNÁNDEZ, S.Y. et al. Seroprevalence of Neospora caninum in dairy goats from Bahia, Brazil. Small Ruminant Res., v.70, p.257-259, 2007.

VARASCHIN, MS.; GUIMARÃES, A.M.; HIRSCH, C. et al. Fatores associados a soroprevalência de Neospora caninum e Toxoplasma gondii em rebanhos caprinos na região sul de Minas Gerais. Pesqui. Vet. Bras., v.31, p.53-58, 2011. 